\title{
The 2005 Galápagos humpback whale expedition: a first attempt to assess and characterise the population in the Archipelago
}

\author{
Fernando Félix ${ }^{1}$, Daniel M. Palacios ${ }^{2,3}$, Sandie K. Salazar ${ }^{4}$, Susana Caballero $^{5}$, Ben Haase $^{1}$ And JéSSica Falconí $^{6}$ \\ Contacte-mail:fefelix90@hotmail.com
}

\begin{abstract}
It has been known for some time that humpback whales (Megaptera novaeangliae) occur in waters of the Galápagos Islands, an oceanic archipelago located $1,000 \mathrm{~km}$ west of Ecuador, South America $\left(1^{\circ} \mathrm{S}, 91^{\circ} \mathrm{W}\right)$, but their presence there has been poorly documented. Although presumed, no linkage has been established between Galápagos and southeast Pacific humpback whales (Breeding Stock G), the nearest breeding stock. An expedition to Galápagos was carried out between 31 August and 10 September 2005 to document the presence of humpback whales, their distribution, and their relationship to other stocks in the Pacific. Surveys covered $722 \mathrm{~km}$ of the central and southern parts of the archipelago. Only one adult with a newborn calf was found at Santa Fé Island $\left(0^{\circ} 47^{\prime} \mathrm{S}, 90^{\circ} 05.1^{\prime} \mathrm{W}\right)$, yielding an encounter rate of 0.27 whales per $100 \mathrm{~km}$ of survey. A hydrophone with a response frequency range of $0.25-25 \mathrm{kHz}$ was dropped 25 times, but no whale sounds were heard. A skin sample was obtained by darting of the adult at Santa Fé, and was used for genetic analysis of the mtDNA control region. The haplotype of the Galápagos specimen has been found in a few individuals sampled previously off Colombia, Ecuador and the Antarctic Peninsula, thus establishing at least some degree of relatedness with Breeding Stock G. The observations, combined with a compilation of historical and recent sighting information in the archipelago, support the idea that Galápagos is a breeding area for the species. Further studies are needed to establish the level of discreteness, size and other basic aspects of the Galápagos humpback whale population.
\end{abstract}

KEYWORDS: SOUTH AMERICA; GALÁPAGOS ISLANDS; BREEDING GROUNDS; HUMPBACK WHALE; SURVEY-VESSEL; OPPORTUNISTIC SIGHTINGS; GENETICS

\section{INTRODUCTION}

The importance of the Galápagos Islands for large cetaceans has been known for a long time, particularly for sperm whales (Physeter macrocephalus; Townsend, 1935; Whitehead and Hope, 1991). However, in the past few decades, a number of scientific expeditions have highlighted the importance of the archipelago's waters for several other cetacean species, including both baleen and toothed whales (Alava, 2002; Clarke, 1962; Clarke et al., 2002; Leveque, 1963; Loesch, 1966; Lyrholm et al., 1992; Palacios, 1999; Palacios, 2003; Palacios et al., 2000; Whitehead, 1986). Despite the existence of confirmed observations of humpback whales (Megaptera novaeangliae) in Galápagos, mostly made by naturalist guides (Day, 1994; Jackson, 1993; MacFarland, 1977; Merlen, 1995), the low number of records suggests that the species is not common in the waters of the archipelago. This could be due not only to a potentially small population using the archipelago, but to a comparatively low search effort by the above-mentioned expeditions in the nearshore areas where humpback whales are expected to occur.

The nearest humpback whale population to Galápagos is the southeast Pacific stock (also referred to as Breeding Stock G; see IWC, 1998), which is distributed along the coast of western South America. A number of studies based on photo-identification (Acevedo et al., 2007; Flórez-González et al., 1998; Stevick et al., 2004) and genetics (Caballero et al., 2001; Félix et al., 2007; Olavarria et al., 2007), have identified the breeding areas for Breeding
Stock G off northwestern South America, and the corresponding feeding areas off the Antarctic Peninsula and the Magellan Strait. However, so far no link has been established between Galápagos and South American humpback whales.

The 'Galápagos Humpback Whale Expedition' was conducted during the austral winter of 2005. The expedition aimed to establish the identity and status of the humpback whales that occur in Galápagos in order to create a knowledge baseline for management purposes. The study was made in the context of a long-term investigation of the southeast Pacific humpback whale stock that the Ecuadorian Foundation for the Study of Marine Mammals (Fundación Ecuatoriana para el Estudio de Mamíferos Marinos, FEMM) has been conducting along the coast of Ecuador since 1991 (Félix and Haase, 2005; Félix and Haase, 2001). The most relevant findings from this expedition are presented here and a molecular comparison is made with continental whales in a first attempt to establish the identity of Galápagos humpback whales. A compilation of historical and recent humpback whale records in Galápagos are also presented to provide a clearer picture of the distribution and temporal occurrence of the species within the archipelago. This effort is highly relevant to one of the key aspects highlighted in a regional conservation strategy recently designed for the southeast Pacific humpback whale population (Flórez-Gonzáles et al., 2007), which calls for the generation of basic information from less-studied areas within the breeding grounds that could be considered critical for the species.

\footnotetext{
${ }^{1}$ Museo de Ballenas, Av. Enriquez, Gallo entre calles 47 y 50, Salinas, Ecuador.

${ }^{2}$ Joint Institute for Marine and Atmospheric Research, University of Hawai'i at Manoa, 1000 Pope Road, MSB 312, Honolulu, HI 96822, USA.

${ }^{3}$ NOAA, NMFS, SWFSC, Environmental Research Division, 1352 Lighthouse Avenue, Pacific Grove, CA 93950-2097, USA.

${ }^{4}$ Galapagos Academy Institute of Arts and Sciences (GAIAS)-USFQ, Puerto Baquerizo Moreno, San Cristóbal, Galápagos.

${ }^{5}$ Laboratorio de Ecología Molecular de Vertebrados Acuáticos, Departamento de Ciencias Biológicas, Universidad Los Andes, Carrera 1 No. 18A-10, Bogotá,

Colombia

${ }^{6}$ Fundación Ecuatoriana para el Estudio de Mamíferos Marinos (FEMM). Salinas, Ecuador.
} 


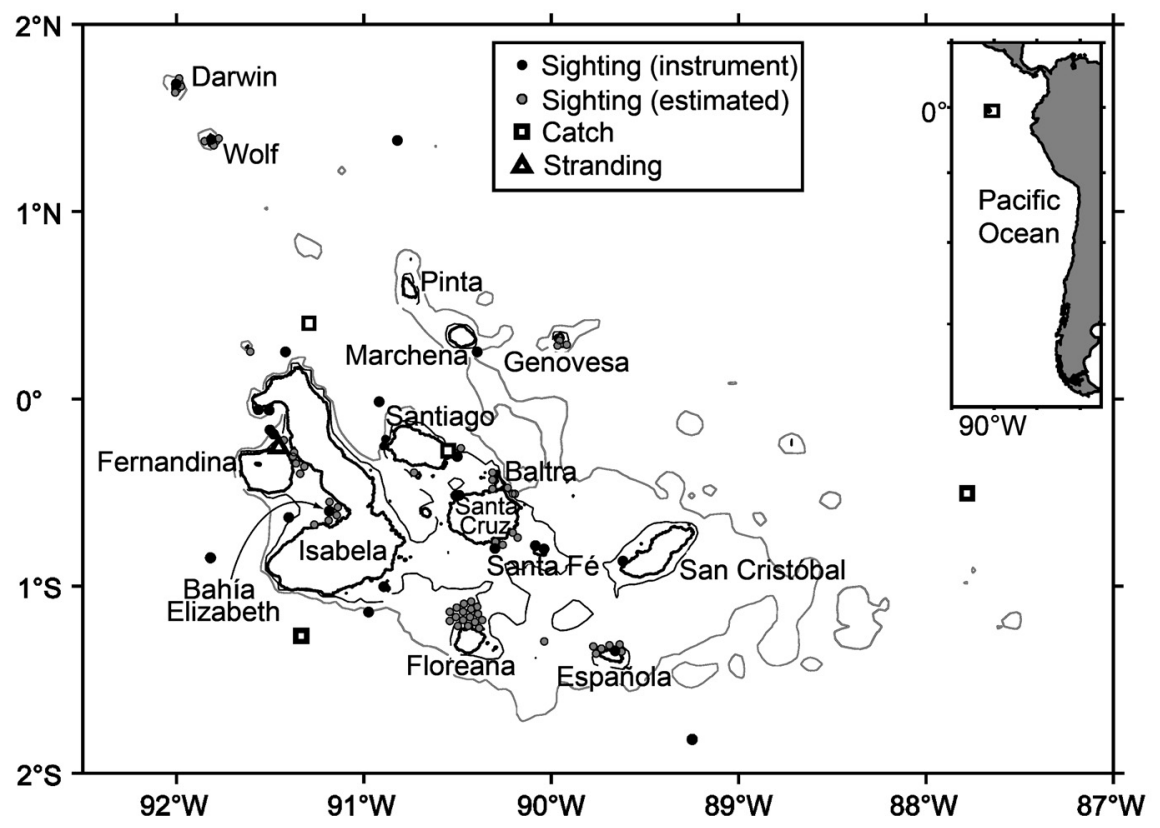

Fig. 1. Distribution of 89 historical and recent humpback whale records in the Galápagos Islands (see Appendix 1 for sources). Bathymetric contours for the 200m (thin black line) and 1,000m (thin grey line) isobaths are shown. Inset shows the location of the study area in relation to western South America.

\section{MATERIAL AND METHODS}

\section{Study area}

The Galápagos archipelago is formed by a group of 13 large islands $\left(>10 \mathrm{~km}^{2}\right)$, six smaller islands, and over 100 islets and rocks (Jackson, 1993; Snell et al., 1996). It is located $1,000 \mathrm{~km}$ west of the coast of Ecuador, South America $\left(1^{\circ} \mathrm{S}\right.$, $91^{\circ} \mathrm{W}$ ) (Fig. 1). The islands are surrounded by narrow shelves and abrupt slopes, with some shallow areas in the central part of the archipelago. In the outer areas, depth increases rapidly to $3,000 \mathrm{~m}$ or more, particularly in the western and southern regions. A marine protected area extending 40 n.miles $(74.1 \mathrm{~km})$ from the baseline surrounding the entire archipelago and covering an area of about $138,000 \mathrm{~km}^{2}$, was established in 1998 as the 'Galápagos Marine Resources Reserve' (Heylings et al., 2002). The highly productive waters of the archipelago, especially on the western side (Palacios, 2002; Palacios et al., 2006), create favourable conditions for a high abundance and diversity of marine mammals (Palacios and Salazar, 2002; Palacios, 2003).

\section{Historical and recent records}

In preparation for the expedition previous records of humpback whales from three sources were compiled as follows.

(1) Townsend Whaling Charts (Townsend, 1935). Capture locations within Galápagos waters were extracted from monthly maps containing 2,883 humpback whale catch records from North American ('Yankee') pelagic whale vessel logbooks dating from 1761 to 1920 . Each record in the charts corresponds to the location of a whaling ship on a day when one or more whales were taken, and does not necessarily reflect the number of whales caught. These data are available in digital format from the Wildlife Conservation Society (http://www.wcs.org/swhigh_tech_tools/landscapeecology/townsend_charts).

(2) Sighting locations collected in Galápagos waters by scientific observers aboard tuna fishing vessels (Archer et al., 2002; Buckland et al., 1992) and research vessels (Hill et al., 1991; Kinzey et al., 1999) under programmes conducted by the Southwest Fisheries Science Center (SWFSC) of the US NOAA/National Marine Fisheries Service. Sightings collected by a team from Dalhousie University, Canada while conducting sperm whale research in Galápagos (Smith and Whitehead, 1999; Whitehead, 1986) were also included.

(3) Weekly reports by licensed naturalist guides to the Galápagos National Park (GNP) and from a 'Sightings Logbooks Program' created under an inter-institutional agreement between the GNP and the Charles Darwin Foundation (CDF). The objective of this programme is to establish a uniform reporting standard and to improve the quality of information reported by the different users of the Galápagos Marine Resources Reserve. Sightings logbooks are distributed among users, to be completed whenever cetacean sightings are recorded. Tour vessels operating in the Reserve must follow established routes to visitor sites and carry aboard naturalist guides trained in marine mammal identification. About 40 vessels currently participate in the programme. The programme was officially implemented in 2001, but it contains records starting from 1995. The reports are qualitycontrolled for errors and are entered into a database maintained by the CDF (Salazar and Hernandez, 2000). For mapping purposes, the geographic coordinates for records for which only the approximate locality was reported were georeferenced using the GIS software ArcView 3.2 with the animal movement extension. Throughout the text, these positions are referred to as 'estimated' to differentiate them from exact positions obtained directly in the field, which are referred to as 'instrument'.

\section{Surveys}

Between 31 August and 10 September 2005, ten surveys were conducted in the central part of the archipelago aboard four different vessels: three small boats (6-8m in length) 
with outboard engines, and the $12 \mathrm{~m}$ sailboat 'Bronzewing', which was used as a live-aboard platform for seven days. Daily trips lasted 5-12h depending on weather conditions and on finding a safe place to overnight. Surveys were carried out over the shelf of several islands in areas where the presence of humpback whales had previously been reported. Trips plans were made and updated on a daily basis, based on the progress made during the day. For this purpose, the navigation Chart IOA 21 (INOCAR, Ecuador) and a GPS Garmin $60^{\mathrm{TM}}$ were used. In the case of the small boats, observations were made from the cabin's rooftop, about 2$2.5 \mathrm{~m}$ above the waterline. Boats moved at an average speed of $12 \mathrm{kt}\left(22.2 \mathrm{~km} \mathrm{~h}^{-1}\right)$. On the sailboat, which was powered by a small inboard diesel engine, observers were located on the main deck, both at the bow and amidships, at an average height of $1.5 \mathrm{~m}$ above the waterline. The sailboat's speed ranged between 5 and $7 \mathrm{kt}\left(9.3-13 \mathrm{~km} \mathrm{~h}^{-1}\right)$.

Sea state conditions were fairly constant during the study period, ranging between 2 and 3 on the Beaufort scale. When conditions worsened, sighting effort was stopped (this occurred twice). During the observation periods, information on group size and composition, position, heading, speed and general behaviour was obtained. Photographs were taken with a digital camera equipped with a $70-300 \mathrm{~mm}$ zoom lens.

A hydrophone model C10 (Cetacean Research Technology) with a response frequency range of $0.25-25 \mathrm{kHz}$ and a digital voice recorder Archos G-Mini 120 were used for listening and recording whale songs. The hydrophone was used on an irregular basis, in some cases every 60min of survey, especially on the small boats. Aboard the sailboat, the hydrophone was used sporadically at the beginning and end of the daily surveys.

\section{Molecular analysis}

A skin sample was obtained from a humpback whale at Santa Fé Island with a Barnett crossbow equipped with a $60 \mathrm{~cm}-$ long arrow and modified tips (see Lambertsen, 1987). The biopsy was preserved in a solution of dimethylsulfoxide saturated in sodium chloride. Approximately a 520bp fragment of the mitochondrial DNA control region was amplified via the Polymerase Chain Reaction (PCR) using standard reaction conditions (Palumbi, 1996; Saiki et al., 1988). For the PCR, the primer combination t-Pro-whale (5'-TCACCCAAAGCTGRARTTCTA-3') and Dlp8 (5'CCATCGWGATGTCTTATTTAAGRGGAA-3') was used (Baker et al., 1998; Olavarria et al., 2007). The PCR profile used was as follows: an initial denaturation at $95^{\circ} \mathrm{C}$ for $2 \mathrm{~min}$; 36 cycles of $94^{\circ} \mathrm{C}$ for $30 \mathrm{~s}, 55^{\circ} \mathrm{C}$ for $1 \mathrm{~min}, 72^{\circ} \mathrm{C}$ for $1.30 \mathrm{~min}$; and a final extension at $72^{\circ} \mathrm{C}$ for $5 \mathrm{~min}$. Free nucleotides and primers were removed from the PCR products using shrimp alkaline phosphatase and exonuclease I (ExoI, USB) and directly sequenced in both directions using the standard protocols of Big Dye terminator sequencing chemistry on an ABI 3100 automated capillary sequencer (Perkin Elmer).

A $480 \mathrm{bp}$ fragment was analysed for haplotype determination. The sequence was manually edited and aligned using Sequencher 4.1 software (Gene Codes Corporation). The control region haplotype was defined using MacClade (Maddison and Maddison, 2000) and compared with haplotypes previously defined for other humpback whale populations in the South Pacific (Caballero et al., 2001; Félix et al., 2007; Olavarría et al., 2006; Olavarria et al., 2007). Haplotype nomenclature follows Olavarría et al. (2007).

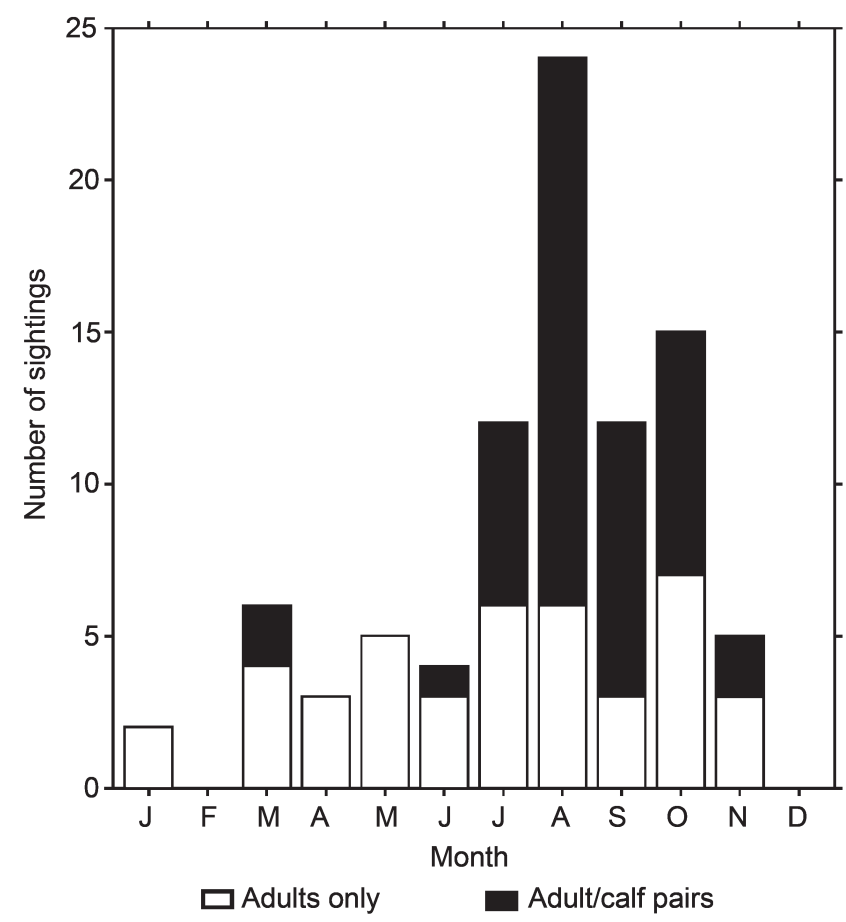

Fig. 2. Frequency distribution per month of historical and recent humpback whale records in the Galápagos Islands for groups containing adults only and adult/calf pairs.

\section{RESULTS}

\section{Historical and recent records}

A total of 89 humpback whale records were obtained, including four captures, one stranding and 84 sightings (Fig. 1, Appendix 1). Most of the records were concentrated around the islands of the central (Santiago, Santa Cruz, Floreana) and western (Isabela) side of the archipelago, although whales were also seen over the shelf of all main islands except for Pinta.

The frequency distribution of sightings per month (including sightings involving adult-calf pairs) is shown in Fig. 2. Humpback whales were recorded over ten different months, with a clear peak between July and October, and with fewer records in May, June and November. In addition, 11 sightings (12.5\%) were made between January and April, including two female-calf pairs.

\section{Visual and acoustic survey effort}

The surveyed areas covered waters around the following islands: west and north of San Cristóbal; east and north of

Table 1

Details of the surveyed areas during the 'Galápagos Humpback Whale Expedition', 31 August-10 September 2005.

\begin{tabular}{llrr}
\hline Date & Survey & $\begin{array}{r}\text { Duration } \\
(\mathrm{hr})\end{array}$ & $\begin{array}{r}\text { Distance } \\
(\mathrm{km})\end{array}$ \\
\hline 31/08/05 & West and NW sides of San Cristóbal & 7.90 & 100.50 \\
$01 / 09 / 05$ & San Cristóbal-Santa Fé-Santa Cruz & 6.16 & 74.50 \\
$03 / 09 / 05$ & Santa Cruz-Santa Fé & 5.21 & 38.60 \\
$04 / 09 / 05$ & Santa Fé-Floreana & 9.25 & 72.50 \\
$05 / 09 / 05$ & Floreana - southeast of Isabela & 11.83 & 91.39 \\
$06 / 09 / 05$ & SE of Isabela-Rábida & 11.48 & 72.28 \\
$07 / 09 / 05$ & Rábida-Baltra & 10.13 & 58.61 \\
$08 / 09 / 05$ & Baltra - north of Santa Cruz & 6.21 & 37.63 \\
$09 / 09 / 05$ & West of Santa Cruz-Puerto Ayora & 7.71 & 93.99 \\
$10 / 09 / 05$ & Santa Cruz-San Cristóbal & 5.40 & 82.36 \\
Total & & 81.33 & 722.36 \\
\hline
\end{tabular}




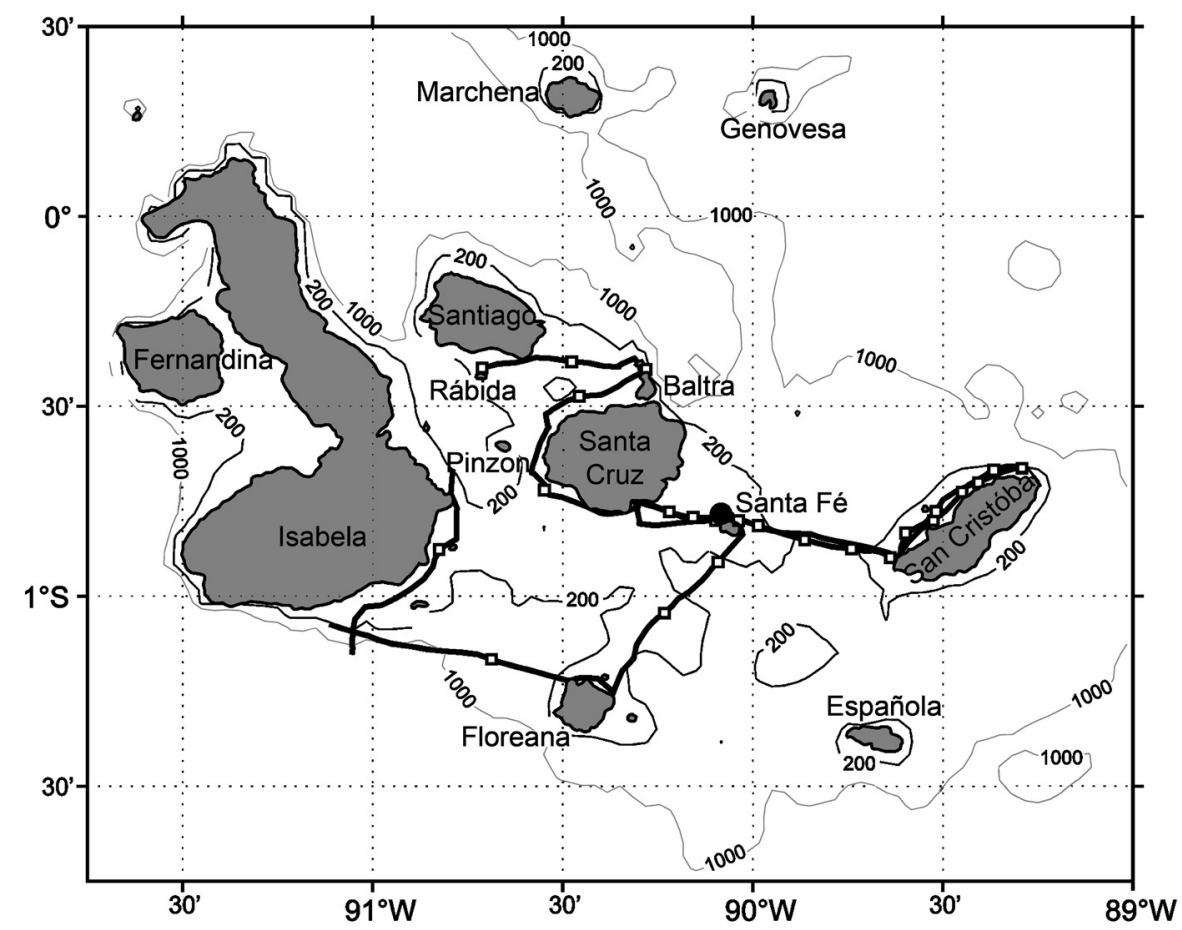

Fig. 3. Survey tracks (bold black line) during the 'Galápagos Humpback Whale Expedition', 31 August10 September 2005. Hollow squares denote the 25 acoustic stations. The black solid circle near the centre of the map indicates the location of the adult/calf pair sighting. The $200 \mathrm{~m}$ and $1000 \mathrm{~m}$ isobaths are shown

Santa Fé; north of Floreana; southeast of Isabela; north, west and south of Santa Cruz; southeast of Santiago; and the waters between them (Fig. 3). The total distance covered was $722.36 \mathrm{~km}$ and the total navigation time was $81.33 \mathrm{hr}$ (Table $1)$. The hydrophone was dropped for $5 \mathrm{~min}( \pm 1 \mathrm{~min})$ at 25 different sites (Fig. 3), but no sounds were heard during the entire expedition.

\section{Encounter rate}

The only humpback whale observation made during the expedition was near Santa Fé Island ( $\left.0^{\circ} 47.6^{\prime} \mathrm{S}, 90^{\circ} 05.1^{\prime} \mathrm{W}\right)$ (Fig. 3). The group was made up of an adult with a small calf, probably a couple of weeks old judging by its very small size and the light grey colour of its skin (Fig. 4). The pair was found over a shallow area of less than $20 \mathrm{~m}$ in depth, northwest of the island. According to the navigation chart IOA 21, Santa Fé Island has a shelf of $100 \mathrm{~m}$ in depth extending some $10 \mathrm{~km}$ on its southeast side, but in the northwest part, where the pair was found, the shelf only extends out to about $3 \mathrm{~km}$. However, the sighting was made over a shallow flat area marked on the navigation chart as

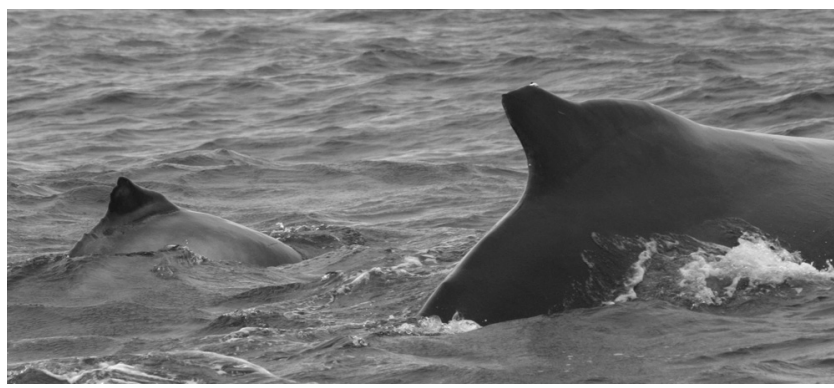

Fig. 4. Humpback whale adult-calf pair encountered at Santa Fé Island. Notice the calf's very small size compared to that of the adult and the lighter colour of its skin.
$13 \mathrm{~m}$ depth and with an area of about $3-4 \mathrm{~km}^{2}$. Photographs of the dorsal fins were taken since none of the animals showed their flukes. The encounter rate for humpback whales during this expedition was of 0.276 whales per $100 \mathrm{~km}$ of survey.

\section{Control region haplotype}

The Galápagos haplotype was identified as SP61, which has previously been found in one individual from mainland Ecuador (Félix et al., 2007), one from Colombia (Olavarria et al., 2007) and two from the Antarctic Peninsula (Olavarría et al., 2006).

\section{DISCUSSION}

\section{Relative abundance and habitat use}

While the GNP-CDF database was useful in establishing that humpback whales may be found in nearshore waters throughout the archipelago, further interpretation is complicated due to three sources of bias in this data set: (1) recording does not follow a systematic effort, making it impossible to obtain estimates of relative abundance; (2) the same animal(s) could be reported by more than one observer at sites visited by multiple vessels in a short time period; and (3) the reports came from lots of observers with different levels of experience in identifying whale species, increasing the possibility of misidentification.

The 2005 ‘Galápagos Humpback Whale Expedition' was the first attempt to quantify the presence of this species in the archipelago. Nevertheless, during the study period, it was not possible to survey all the sites where humpback whales have been reported previously (Fig. 1), particularly the highly productive areas between Isabela and Fernandina Islands. The survey was limited to the central, southern and southeastern parts of the archipelago, over the shelf of several islands and the deep-water zone between them. Since 
extensive areas of the archipelago remained unsurveyed, the findings should not be considered representative of the entire archipelago.

There was a large difference in whale density in the surveyed areas in Galápagos compared to the breeding areas off mainland Ecuador, where the encounter rate was 59 times higher during the same season (Felix et al., 2004). It should be recognised, however, that survey conditions were not the same between these two areas, since sea state conditions are slightly better and faster boats are used at the mainland sites. Despite these differences, the data presented herein support the notion that Galápagos contains a low density of humpback whales, as previous reports have suggested (Day, 1994; Merlen, 1995). It is possible that humpback whales were never abundant in Galápagos, considering that 19th century American whalers concentrated their effort on humpback whales in the continental waters of Panamá, Colombia and Ecuador, while the Galápagos Islands were considered a major whaling area for sperm whales (Townsend, 1935).

A low humpback whale density seems to be characteristic of oceanic archipelagos in the South Pacific. For instance, Gannier (2004) reported encounter rates between 0.35 and 1.54 whales per $100 \mathrm{~km}$ of survey in French Polynesia, which is between 1.3 and 5.7 times higher than for the Galápagos Islands. Although Gannier primarily used a similar $12 \mathrm{~m}$ sailboat, both studies also used data obtained from other types of vessels. Therefore, caution should be exercised with this interpretation, as the data are probably not fully comparable. It is also known that humpback whales show a clustered distribution around archipelagos, with sites of high concentration of animals and extended zones of low densities. In Hawai'i, for example, there is high density in a shallow area known as the Penguin Bank and also in the Four Island area off Maui (Herman and Antinoja, 1977; Salden, 1988). In the Caribbean, $85 \%$ of the entire North Atlantic population concentrates for breeding at Silver and Navidad Banks off the northern Dominican Republic (Winn et al., 1975), although whales can be found as far south as the Lesser Antilles (Swartz et al., 2003). While it is not implausible that such a type of distribution may occur in Galápagos, it seems unlikely that local high whale concentrations have passed unnoticed in an area with such a high level of tourism activities.

A determining factor for the low encounter rate may have been the low observation height onboard the vessels. However, the lack of song detection is supportive of a low whale density at the time of the survey. An alternative explanation to the low encounter rate and to the lack of singers could be that reports of humpback whales in Galápagos correspond to transient animals and/or unusual visitors from other sites in the southeast Pacific. However, the sighting, together with previous records of adult-calf pairs in Galápagos (MacFarland, 1977; Merlen, 1995; see also Appendix 1) provide strong support to the idea that the archipelago's waters are used for more than merely transiting and are probably a calving area for humpback whales.

The predominantly coastal distribution of humpback whales in Galápagos (Fig. 1) is consistent with the habitat preferences reported for the species at the breeding grounds along mainland Ecuador (Felix and Haase, 2005), as well as at other calving areas worldwide (Ersts and Rosenbaum, 2003; Johnston et al., 2007; Smultea, 1994; Vang, 2002). This distribution pattern has local conservation implications because adult-calf pairs could be particularly sensitive to the intense maritime traffic generated by tourism (see Salden, 1988), the main economic activity in Galápagos. Therefore, the overlap between vessel routes and areas of humpback whale presence and the impact of maritime traffic on whale behaviour are aspects that need to be assessed.

\section{Population identity}

Historical and recent records of humpback whales in Galápagos indicated that the species occurred primarily during the austral winter months (Fig. 2, Appendix 1), as is expected for a Southern Hemisphere population during its breeding period in the tropics. The few records from May, June and November could reflect normal variations in the timing of migration, as has been recorded along mainland Ecuador (Félix and Haase, 2001).

However, $12.5 \%$ of the sightings occurred between January and April, leading to the possiblity that at least some of the whales sighted in the early part of the year may belong to a Northern Hemisphere stock. It has been demonstrated that the breeding areas for Northeast Pacific and southeast Pacific humpback whales overlap in waters off Panamá and Costa Rica (Acevedo-Gutiérrez and Smultea, 1995; Rasmussen et al., 2007), and possibly as far south as southern Colombia, where two haplotypes from a North Hemisphere stock have been found (Caballero et al., 2001). Another possibility is that these whales did not migrate and remained during the entire year around Galápagos. The high local productivity, especially in the western part of the archipelago (Palacios, 2002; Palacios et al., 2006), could provide food for non-migrating animals, as has been proposed in other tropical areas with intense upwelling (Papastavrou and Van Waerebeek, 1997). One of these areas is the coast of Perú, a few hundred kilometers southeast of Galápagos, where humpback whales have been reported throughout the entire year (Ramírez, 1988).

The molecular biology study showed a relationship between Galápagos humpback whales and Breeding Stock $\mathrm{G}$, since the same haplotype has been found in Colombia, Ecuador and the Antarctic Peninsula. However, the Galápagos haplotype was not among the most common ones found in Breeding Stock $\mathrm{G}$, as it has only been found four times in about 400 samples from the southeast Pacific and the Antarctic Peninsula (Félix et al., 2007; Olavarria et al., 2007). Genetic (Félix et al., 2007; Olavarría et al., 2006), and photo-identification (Acevedo et al., 2007) studies indicated that Breeding Stock G shows some degree of heterogeneity in its distribution, with at least two welldefined subunits.

The possibility that Galápagos humpback whales could be part of a discrete subunit with a low degree of exchange with the continental population cannot be excluded. Genetic differentiation between continental and insular populations has been found in Northeast Pacific humpback whales breeding at the Revillagigedo Archipelago, relative to whales breeding along central mainland Mexico, only $700 \mathrm{~km}$ apart (Urban et al., 2000). Further sampling and analysis are needed to establish the degree of discreteness, genetic variability and the main lineages in Galápagos, among other key population parameters.

\section{ACKNOWLEDGEMENTS}

The Unidad de Uso Público of the GNP provided access to the reports by naturalist guides and other observers. The following tour vessels have participated in the Sightings Logbooks Program of the GNP-CDF: Albatros, Alta, Andando, Ambassador, Beagle III, Carina, Chatam, Coral I, Cormorant, Delfin II, Diamante, Dorado, Eclipse, 
Expedition, Flamingo I, Garúa, Guantanamera, Isabela II, Islander, Jesus del Gran Poder, Lammer Law, Lobo de Mar, Nemo, Mistral II, Polaris, Pulsar, Reina Silvia, Rembrandt, Sagitta, Samba, San Jose, Santa Cruz, Santa Fe II, Sea Cloud, Sky Dancer, Sullivan and Bravo Bravo. Conservation vessels operated by the GNP or CDF that have participated in the program include: Guadalupe River, Sirenian, Beagle and Spondylus. The naturalist guides and other observers who have diligently collected the humpback whale sightings in the GNP-CDF database include the following. Byron Aguirre, Juan Carlos Avila, Luis Cadena, Monica Calvopiña, Jaime Carrillo, Rodolfo Castañeda, Pablo Castañeda, Alfredo Cevallos, Mafer Davila, Philippe Deger, Luis Die, Bitinia Espinoza, Klaus Fielsch, Marcel Filudo, Lynn Fowler, Peter Freire, Margoth Freire, Antonio Gallardo, Jason Gallardo, Gilda Gonzales, Jonathan Green, Franklin Guaranda, Bernardo Gutiérrez, Tanya Helmig, Carlos Inga, Macarena Iturralde, Jacinto Jaramillo, Julian Jaya, Harry Jimenez, Carlos King, Grace Loza, Cindy Manning, Celso Montalvo, Roberto Naranjo, Jaime Nicolaide, Juan Ojeda, Washington Paredes, Renato Pérez, Rafael Pesantes, Cornelio Rodriguez, Luis Rodriguez, Giovana Romero, Jhonny Romero, Rafael Rubro, Edilberto Rugel, José Sabando, Gino Salazar, Sandie Salazar, Bolivar Sanchez, Paula Tagle, Walter Torres, Dora Ulloa, Silvia Vargas, Luis Verdesoto and Dolores Villacreses.

Tim Gerrodette (SWFSC) and Hal Whitehead (Dalhousie University) kindly contributed additional historical sightings. Kristin Rasmussen helped with data extraction from the digital version of the Townsend Whaling Charts. Dan Krofcheck assisted during the first days of the expedition. Susan Chivers, Kerri Danil, and Janet Lowther of SWFSC kindly loaned the biopsy equipment. We thank Eric Mielhe, Emerik Mote, Gustavo Esperanza, and Virna Cedeño from 'Concepto Azul' for their help in analysing the sample at their laboratory in Guayaquil, Ecuador. We also thank Carlos Olavarría for allowing us to compare control region sequences from our sample with his unpublished data sets. This project was funded through grants from the Whale and Dolphin Conservation Society (UK), the Fellowship Program for Conservation of Ecociencia (Ecuador) and the Frederick and Margaret L. Weyerhaeuser Foundation (USA), with further support from William Rossiter (Cetacean Society International) and Marco Albarracín (Ecociencia). DMP was supported by award No. N00014-05-1-0045 from the US Office of Naval Research, National Oceanographic Partnership Program. The expedition was authorised by the Ecuadorian Undersecretary of Environment through letter No 000544 SGAC-MA/04 of 3 December 2004, and endorsed through letter No. 000543 SGAC-MA/04. Additionally, the GNP issued authorisation No. PC-13-05 of 18 July 2005 to conduct the expedition, and authorisation No. 080/05 PNG of 2 September 2005 to export samples from Galápagos. Diane Gendron, Hal Whitehead, Greg Donovan, Alex Zerbini and an anonymous reviewer provided valuable comments on earlier versions of this manuscript.

\section{REFERENCES}

Acevedo-Gutiérrez, A. and Smultea, M.A. 1995. First records of humpback whales including calves at Golfo Dulce and Isla del Coco, Costa Rica, suggesting geographical overlap of northern and southern hemisphere populations. Mar. Mammal Sci. 11(4): 554-60.

Acevedo, J., Rasmussen, K., Félix, F., Castro, C., Llano, M., Secchi, E., Saborío, M.T., Aguayo-Lobo, A., Haase, B., Scheidat, M., Dalla Rosa, L., Olavarria, C., Forestell, P., Acuña, P., Kaufman, G. and Pastene, L.A. 2007. Migratory destinations of humpback whales, Megaptera novaeangliae from the Magellan Strait feeding ground, southeast Pacific. Mar. Mammal Sci. 23(2): 453-63.
Alava, J.J. 2002. Registro y abundancia relativa de mamiferos marinos durante el crucero oceanografico insular B/I Orion en las islas Galapagos y sus alrededores. Acta Oceanogr fica del Pacfico 11(1): 165-72. [In Spanish].

Archer, F., Gerrodette, T. and Jackson, A. 2002. Preliminary estimates of the annual number of sets, number of dolphins chased, and number of dolphins captured by stock in the tuna purse-fishery in the eastern tropical Pacific, 1971-2000. US Dep. Commer. NOAA-NMFS-SWFSC Admin. Report LJ-02-10. 28pp.

Baker, C.S., Flórez-González, L., Abernethy, B., Rosenbaum, H.C., Slade, R.W., Capella, J. and Bannister, J.L. 1998. Mitochondrial DNA variation and maternal gene flow among humpback whales of the Southern Hemisphere. Mar. Mammal Sci. 14(4): 721-37.

Buckland, S.T., Cattanach, K.L. and Anganuzzi, A.A. 1992. Estimating trends in abundance of dolphins associated with tuna in the eastern tropical Pacific Ocean, using sightings data collected on commercial tuna vessels. Fish. Bull. 90: 1-12.

Caballero, S., Hamilton, H., Jaramillo, H., Capella, J., Flórez-González, L., Olavarría, C., Rosenbaum, H.C., Guhl, F. and Baker, C.S. 2001. Genetic characterisation of the Colombian Pacific Coast humpback whale population using RAPD and mitochondrial DNA sequences. Mem. Queensl. Mus. 47: 459-64.

Clarke, R. 1962. Whale observation and whale marking off the coast of Chile in 1958 and from Ecuador towards and beyond the Galápagos Islands in 1959. Norsk Hvalfangsttid. 51(7): 265-87.

Clarke, R., Félix, F., Paliza, O. and Brtnik, P. 2002. Ballenas y delfines observados por la expedicion Ballenas Libres durante el crucero oceanografico CO-II-01 entre Guayaquil y las Islas Galapagos del 17 Septiembre al 9 de octubre de 2001. Acta Oceanográfica del Pacífico 11(1): 315-25. [In Spanish].

Day, D. 1994. List of cetaceans seen in Galapagos. Noticias de Galápagos 53: 5-6.

Ersts, P.J. and Rosenbaum, H.C. 2003. Habitat preference reflects social organization of humpback whales (Megaptera novaeangliae) on a wintering ground. J. Zool., London. 260: 337-45.

Félix, F. and Haase, B. 2001. The humpback whale off the coast of Ecuador, population parameters and behavior. Revista de Biología Marina $y$ Oceanografía 36(1): 61-74.

Félix, F. and Haase, B. 2005. Distribution of humpback whales along the coast of Ecuador and management implications. J. Cetacean Res. Manage. 7(1): 21-29.

Félix, F., Haase, B., Bearson, B., Torres, S. and Falconi, J. 2004. Scientific and educational activities in Ecuador during 2004. Report to the Whale and Dolphin Society, England, December 2004. 28pp. [Available from: www.wdcs.org].

Félix, F., Caballero, S. and Olavarría, C. 2007. A preliminary assessment of the genetic diversity in humpback whales (Megaptera novaeangliae) from Ecuador and population differentiation with other Southern Hemisphere breeding grounds and feeding areas. Paper SC/59/SH11 presented to the IWC Scientific Committee, May 2007, Anchorage, USA (unpublished). [Paper available from the Office of this Journal]. 11pp.

Flórez-Gonzáles, L., Avila, I.C., Capella, J.C., Falk, P., Felix, F., Gibbons, J., Guzman, H.M., Haase, B., Herrera, J.C., Peña, V., Santillan, L., Tobon, I.C. and Van Waerebeek, K. 2007. Estrategia para la Conservacion de la Ballena Jorobada del Pacifico Sudeste. Lineamientos para un plan de accion regional e iniciativas nacionales, Fundacion Yubarta, Cali, Columbia. 106pp. [In Spanish].

Flórez-González, L., Capella, J., Haase, B., Bravo, G.A., Félix, F. and Gerrodette, T. 1998. Changes in winter destinations and the northernmost record of southeastern Pacific humpback whales. Mar. Mammal Sci. 14(1): 189-96.

Gannier, A. 2004. The large-scale distribution of humpback whales (Megaptera novaeangliae) wintering in French Polynesia during 19972002. Aquat. Mamm. 30(2): 227-36.

Herman, L.M. and Antinoja, R.C. 1977. Humpback whales in the Hawaiian breeding waters: population and pod characteristics. Sci. Rep. Whales Res. Inst., Tokyo 29: 59-85.

Heylings, P., Bensted-Smith, R. and Altamirano, M. 2002. Zonificacion e historia de la Reserva Marina de Galapagos. pp.10-21. In: Danulat, E. and Edgar, G.J. (eds). Reserva Marina de Galapagos, Linea Base de la Bioversidade. Fundacion Charles Darwin/Servicio Parque Nacional Galapagos, Santa Cruz, Galapagos, Ecuador. [In Spanish].

Hill, P.S., Jackson, A. and Gerrodette, T. 1991. Report of a marine mammal survey of the eastern tropical Pacific aboard the research vessel McArthur July 28-December 6, 1990. US Dep. Commer. NOAA Tech. Memo. NOAA-TM-NMFS-SWFSC-159. 142pp.

International Whaling Commission. 1998. Report of the Scientific Committee. Rep. int. Whal. Commn 48:53-118.

Jackson, M.H. 1993. Galápagos, a Natural History. University of Calgary Press, Calgary, Canada. $315 \mathrm{pp}$. 
Johnston, D., Chapla, M., Williams, L.E. and Mattila, D.K. 2007. Identification of humpback whale Megaptera novaeangliae wintering habitat in the northwestern Hawaiian Islands using spatial habitat modelling. Endangered Species Research 3: 249-57.

Kinzey, D., Gerrodette, T., Barlow, J., Dizon, A., Perryman, W., Olson, P. and Von Saunder, A. 1999. Marine mammal data collected during a survey in the eastern tropical Pacific Ocean aboard the NOAA ships McArthur and David Starr Jordan and the UNOLS ship Endeavour, July 31-December 9, 1998. US Dept. Commer. NOAA-TM-NMFS-SWFC 283. 113pp.

Lambertsen, R.H. 1987. A biopsy system for large whales and its use for cytogenetics. J. Mammal. 68(2): 443-45.

Leveque, L. 1963. Notes sur quatre cetaces de l'Ocean Pacifique (Ecuador et Galapagos). Mammalia 27: 608-09. [In French].

Loesch, H. 1966. Observacion de ballenas en aguas ecuatorianas. Boletín Científico y Técnico 1(4): 3-17.

Lyrholm, T., Kerr, I., Galley, L. and Payne, R. 1992. Report of the 'Expedición Siben' Ecuador 1988/89. Whale Conservation Institute, Lincoln, MA, USA (unpublished). 37pp.

MacFarland, J. 1977. Whales in Galapagos - a personal viewpoint. Not. Gal. 26: 19-21.

Maddison, D.R. and Maddison, W.P. 2000. MacClade version 4: analysis of phylogeny and character evolution. Sinauer, Sunderland, MA.

Merlen, G. 1995. A Field Guide to the Marine Mammals of the Galapagos. Instituto Nacional de Pesca, Guayaquil, Ecuador. 130pp.

Olavarría, C., Aguayo, A., Acevedo, J., Medrano, L., Thiele, D. and Baker, C.S. 2006. Genetic differentiation between two feeding areas of the Eastern South Pacific humpback whale population: update on SC/57/SH3. Paper SC/A06/HW29 presented to the IWC Workshop on Comprehensive Assessment of Southern Hemisphere Humpback Whales, Hobart, Tasmania, 3-7 April 2006 (unpublished). 7pp. [Paper available from the Office of this Journal].

Olavarria, C., Baker, C.S., Garrigue, C., Poole, M., Hauser, N., Caballero, S., Florez-Gonzalez, L., Brasseur, M., Bannister, J., Capella, J., Clapham, P., Dodemont, R., Donoghue, M., Jenner, C., Jenner, M.N., Moro, D., Oremus, M., Paton, D. and Russell, K. 2007. Population structure of South Pacific humpback whales and the origin of the eastern Polynesian breeding grounds. Mar. Ecol. Prog. Ser. 330: 257-68.

Palacios, D. and Salazar, S. 2002. Cetáceos. pp.291-304. In: Danulat, E. and Edgar, G.J. (eds). Reserva Marina de Galapagos, Linea de Base de la Biodiversidad. Fundacion Charles Darwin/Servicio del Parque Nacional Galapagos, Santa Cruz, Galapagos, Ecuador. [In Spanish].

Palacios, D.M. 1999. Marine Mammal Research in the Galapagos Islands: The 1993-94 Odyssey Expedition. Ocean Alliance, Lincoln. 46pp.

Palacios, D.M. 2002. Factors influencing the island-mass effect of the Galapagos Islands. Geophys. Res. Lett. 29(23): 2134.

Palacios, D.M. 2003. Oceanographic conditions around the Galapagos Archipelago and their influence on cetacean community structure, Oregon State University, Corvallis, Oregon. 178pp.

Palacios, D.M., Bograd, S.J., Foley, D.G. and Schwing, F.B. 2006. Oceanographic characteristics of biological hot spots in the North Pacific: a remote sensing perspective. Deep-Sea Res. II 53(3-4): 250-69.

Palacios, D.M., Clark, R.A., Baraff, L., Jones, J., Johnson, G.E. and Johnson, C. 2000. Voyage of the Odyssey - Galapagos: cruise report no. 2, 22 April-5 May 2000. Submitted to Galapagos National Park Service, Direccion General de Intereses Maritimos de la Armada Nacional, Charles Darwin Research Station, Capitania de Puerto Ayora. Puerta Ayora, Is. Galapagos, Ecuador, 12 May 2000. Unpublished.

Palumbi, S.R. 1996. Nucleic acids II: the polymerase chain reaction. pp.205-47. In: Hillis, D., Moritz, C. and Mable, B.K. (eds). Molecular Systematics. Sinauer Associates, Sunderland, MA
Papastavrou, V. and Van Waerebeek, K. 1997. A note on the occurrence of humpback whales (Megaptera novaengliae) in tropical and subtropical areas: the upwelling link. Rep. int. Whal. Commn 47: 945-47.

Ramírez, P. 1988. La ballena jorobada Megaptera novaeangliae en la costa norte del Perú. Periodos 1961-1966 y 1975-1985. Bol. Lima 56: 91-96. [In Spanish].

Rasmussen, K., Palacios, D., Calambokidis, J., Saborio, M.T., Dalla Rosa, L., Secchi, E.R., Steiger, G.H., Allen, J.M. and Stone, G. 2007. Southern Hemisphere humpback whales wintering off Central America: insights from water temperature into the longest mammalian migration. Biology Letters 3(3): 302-05.

Saiki, R.K., Gelfand, D.H., Stoffel, S., Scharf, S.J., Higuchi, R., Horn, G.T., Mullis, K.B. and Erlich, H.A. 1988. Primer-directed amplification of DNA with a thermostable DNA polymerase. Science 239: 487-91.

Salazar, S.K. and Hernandez, J. 2000. Proyecto bi-instituticional (ECCD-SPNG) de bitacoras de avistamientos. Eastacion Cientifica Charles Darwin, Enero 2000. Galapagos, Ecuador (unpublished). [In Spanish].

Salden, D.R. 1988. Humpback whale encounter rates offshore of Maui, Hawaii. J. Wildl. Manage. 52(2): 301-04.

Smith, S.D. and Whitehead, H. 1999. Distribution of dolphins in Galapagos waters. Mar. Mammal Sci. 15(2): 550-55.

Smultea, M.A. 1994. Segregation by humpback whale (Megaptera novaeangliae) cows with a calf in coastal habitat near the island of Hawaii. Can. J. Zool. 72(5): 805-11.

Snell, H.M., Stone, P.A. and Snell, H.L. 1996. A summary of geographical characteristics of the Galapagos Islands. J. Biogeog. 23(5): 619-24.

Stevick, P.T., Aguayo, A., Allen, J., Avila, I.C., Capella, J., Castro, C., Chater, K., Dalla Rosa, L., Engel, M.H., Felix, F., Florez-Gonzalez, L., Freitas, A., Haase, B., Llano, M., Lodi, L., Munoz, E., Olavarria, C., Secchi, E., Scheidat, M. and Siciliano, S. 2004. Migrations of individually identified humpback whales between the Antarctic peninsula and South America. J. Cetacean Res. Manage. 6(2): 109-13.

Swartz, S.L., Cole, T., McDonald, M.A., Hildebrand, J.A., Oleson, E.M., Martinez, A., Clapham, P.J., Barlow, J. and Jones, M.L. 2003. Acoustic and visual survey of humpback whale (Megaptera novaeangliae) distribution in the Eastern and Southeastern Caribbean Sea. Caribb. J. Sci. 39(2): 195-208.

Townsend, C.H. 1935. The distribution of certain whales as shown by logbook records of American whaleships. Zoologica (NY) 19(1-2): 1$50+6$ maps.

Urban R, J., Jaramillo, A., Aguayo, L., Ladron de Guevara, P., Salinas, M., Alvarez, C., Medrano, L., Jacobsen, J., Balcomb, K., Claridge, D., Calambokidis, J., Steiger, G., Straley, J., von Ziegesar, O., Waite, M., Mizroch, S., Dahlheim, M., Darling, J. and Baker, S. 2000. Migratory destinations of humpback whales wintering in the Mexican Pacific. $J$. Cetacean Res. Manage. 2(2): 101-10.

Vang, L. 2002. Distrubution, abundance and biology of group V humpback whales Megaptera novaeangliae: a review, Environmental Protection Agency, Queensland Parks and Wildlife Service, Australia. 19pp.

Whitehead, H. 1986. Sperm whales of the Galapagos Islands, FebruaryApril 1985. Report to Green Island Foundation, Connecticut Cetacean Society, Olle Engkvist Foundation, Charles Darwin Research Station, Galapagos National Park Service and INOCAR (unpublished). 49pp.

Whitehead, H. and Hope, P.L. 1991. Sperm whalers off the Galápagos Islands and in the Western North Pacific, 1830-50: ideal free whalers? Ethol. Sociobiol. 12: 147-61.

Winn, H.E., Edel, R.K. and Taruski, A.G. 1975. Population estimate of the humpback whale (Megaptera novaeangliae) in the West Indies by visual and acoustic techniques. J. Fish. Res. Bd Can. 32(4): 499-506. 
$\frac{\pi}{2 \pi}$

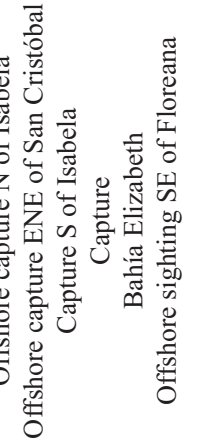

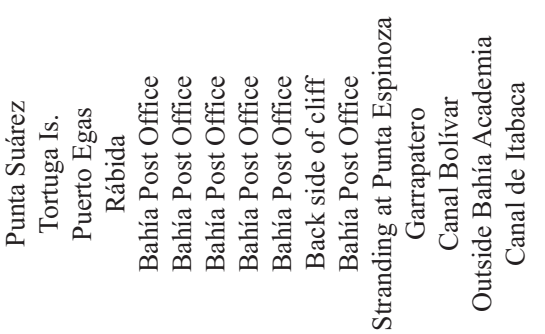

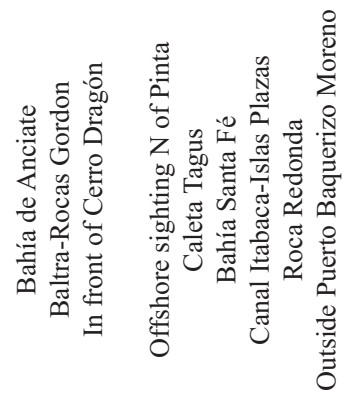

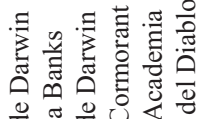

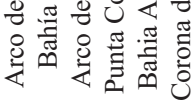

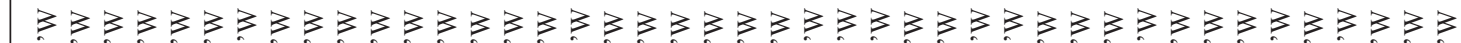

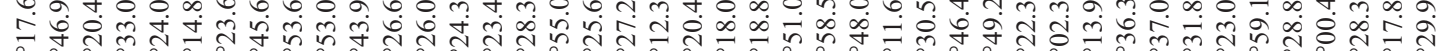

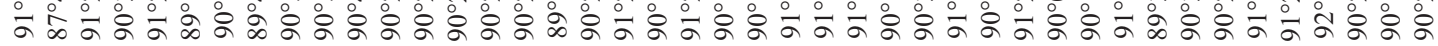

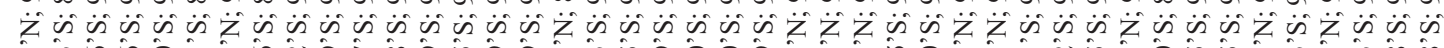

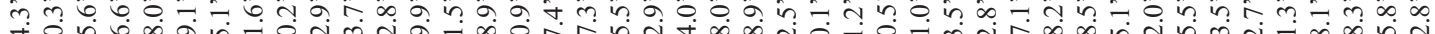

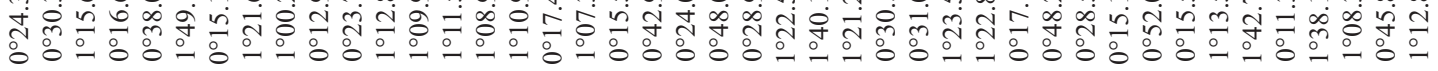

बृु 


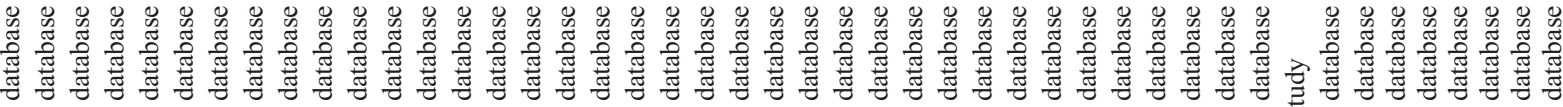

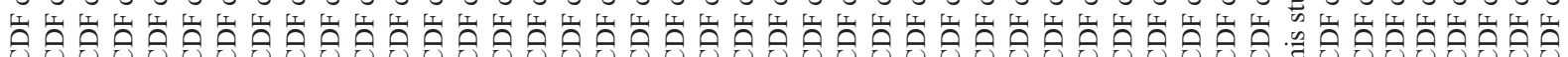

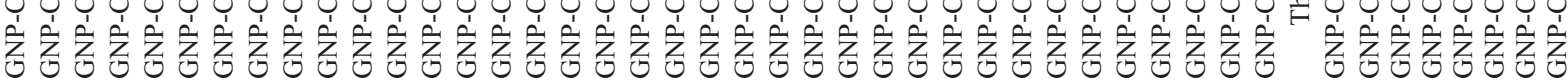

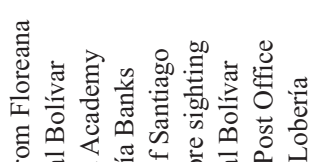

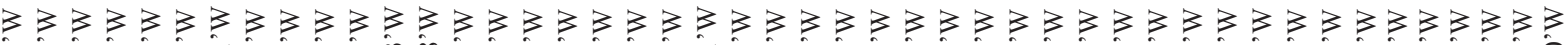

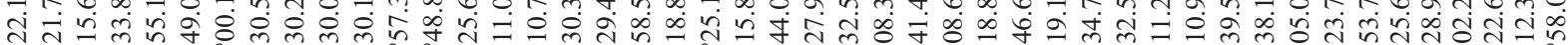

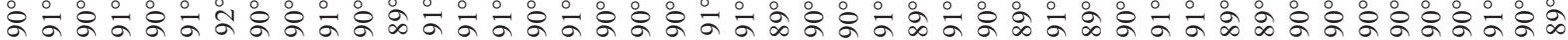

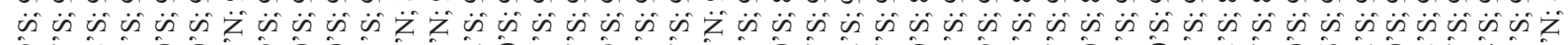

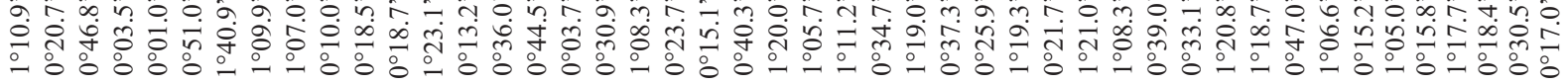

